\title{
IS IT POSSIBLE TO USE MOBILE TECHNOLOGY AS AN INSTRUMENT FOR TEACHING SCIENCE OF THE CURRENT GENERATION OF STUDENTS?
}

\author{
Jan VÁLEK, Masarykova univerzita \\ Petr SLADEK*, Masarykova univerzita
}

Přijato: 25. 9. 2015 / Akceptováno: 17. 11. 2015

Typ článku: Teoretická studie

DOI: $10.5507 /$ jtie.2016.004

Abstract: Interaction of mobile technologies and pupils who work with them every day raises the question if there is a need to seek new teaching methods for pupils from generation Z. Pupils' education would not necessarily occur only at school but whenever the pupils have time. The results of the survey offer some applications for mobile technology that can help teachers in the educational process in the natural science.

Key words: mobile technology, education, science.

\section{MOHOU BÝT MOBILNÍ TECHNOLOGIE PROSTŘEDKEM PRO VÝUKU PŘÍRODOVĚDNÝCH PŘEDMĚTŮ SOUČASNÉ GENERACE ŽÁKŮ?}

Resumé: Vzájemná interakce mobilnich technologií a žáků, kteři s nimi dennodenně přicházi do styku, navozuje otázku, zda není potřeba hledat pro žáky z generace $Z$ nové výukové metody. Vzdělávání žáků by pak nemuselo nutně probihat pouze ve škole nebo v čase vyhrazeném domácí prípravě, ale kdykoliv, kdy má žák časový prostoj, kdy na cokoliv čeká. Z výsledkù orientačního výzkumného šetrení nabídneme některé aplikace pro mobilní technologie, které mohou $v$ tomto ohledu pomoci učitelüm při jejich zakomponování do vyučovacího procesu v př́rodních védách.

Klíčová slova: mobilní technologie, vzdělávání, př́írodní vědy.

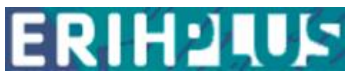

*Autor pro korespondenci: sladek@ped.muni.cz 


\section{1 Úvod}

Současná výuka, nejen v českých školách, je stále více digitalizována. Díky tomuto trendu a zavádění tabletů do škol můžeme pozorovat, $\mathrm{v}$ jak dynamické době se naše společnost nachází. Velice krátká doba nás dělí od okamžiku, kdy Apple představil iPad (leden 2010), první tablet současného typu. To se samozřejmě muselo odrazit také ve vzdělávání, jak jsme již uvedli. Již od školního roku 2012/2013 některé základní školy tato zařízení aktivně začleňují do své výuky (Edukační laboratoř, 2015).

Co tento krok do škol přináší? Jsou již dnes patrná nějaká pozitiva, která přinesly tablety do výuky?

\section{Generace $\mathbf{Y}, \mathbf{Z}$}

Vzájemná interakce mobilních technologií a žáků, kteří s nimi dennodenně přichází do styku, navozuje otázku, zda není potřeba hledat pro žáky z Generace $Z$ nové výukové metody. To může být výchozí otázka pro současné prírodovědné vzdělávání. To by se pak nemuselo nutně probíhat pouze ve škole nebo $\mathrm{v}$ čase vyhrazeném domácí prípravě, ale kdykoliv, kdy má žák časový prostoj, když na cokoliv čeká.

\subsection{Generace $Y$}

Generace Y (někdy také Net Generation) je 1. generace, která od dětství může používat ICT. Toto označení bylo poprvé použito v časopise Advertising Age (Generation Y, 1993). Dále s tímto pojmem pracovali D. a J. Oblingerovi (2005), kteří uvádějí, že do této generace spadají lidé narození v mezi roky 1982-1991. Generace Y je tak podle rozmezí let, kdy se narodili její účastníci, označována jako přímý následovník Generace X (osob narozených mezi lety 1965-1982). Dětmi př́slušníků Generace Y jsou až př́slušníci Generace Alfa.

Základní charakteristiky determinující vzdělávací proces Generace Y jsou, jak uvádějí D. a J. Oblingerovi (2005): využívání digitálních technologií je každodenní a samozřejmou součástí života, intuitivně a bez návodu k obsluze, výrazná dominance vizuální gramotnosti nad čtenářskou, aktivní multitasking a preferování rychlosti řešení problému před přesností a správností, sdílení informací různého druhu a očekávaná adekvátní odezva.

\subsection{Generace $Z$}

Vymezení věkového rozpětí i vlastního popisu této generace se různí. Robinson (2013) uvádí, že se př́slušníci této generace mohli narodit v rozmezí let 1995-2014, Schroer (2004) uvádí rozmezí 1995-2012 a Tulgan (2013) pak 1993-2014. Co se tedy věku týče, jedná se o současné žáky základních a středních škol, v některých případech již nastupují na školy vysoké.

Protože jsou následovníky (nikoli však jejich př́mí potomci) Generací X nebo $\mathrm{Y}$, budou mít některé znaky stejné, dokonce i silnější. Např́klad jejich potřeba být on-line je mnohem silnější než u Generace Y. Obdobně je to také s ICT a jinou digitální technikou, v podstatě neznají svět a život bez ní. Reálný život a neúspěchy v něm si kompenzují virtuálním životem, kde bývají často úspěšnější, v kolektivu uznávaní. Právě život $v$ těchto dvou světech podporuje jejich individualismus. Jsou proto ochotni vykonávat 
takovou práci, ve které získají nové vědomosti a dovednosti. Měli by být nositeli nových řešení oproti zaběhlým postupům.

Vzhledem $\mathrm{k}$ výše uvedenému není pro učitele $\mathrm{z}$ Generace $\mathrm{X}$ nebo $\mathrm{Y}$ snadné najít společnou komunikační vlnu s žáky spadající do Generace $Z$. Je tedy vhodné aplikovat znalosti o uvedených skupinách do praxe.

Podle Hartla (2000) a Průchy (1995) můžeme říci, že hlavním těžištěm vzdělávacího procesu je řešení problémů $\mathrm{z}$ běžného života žáka. Dále následuje žákovská skupinová práce, kde submisivní roli hraje memorování a drilování. Celkově je kladen velký důraz na tvořivé myšlení žáků, kteří se dokáží kvalitněji vypořádat s problémy, na které je škola ve výuce nedokázala připravit. Nepředpokládala, že by mohly nastat. Což jsou právě atributy vzdělávacího procesu, které př́slušníci Generace $Z$ akceptují a dokáží s nimi pracovat.

\section{Digitální vzdělávání a mobilní technologie}

\subsection{Ukotvení použivání digitálních technologií v Rámcovém vzdělávacím programu pro základní vzdělávání}

Problematika digitálních mobilních technologií a ICT ve vzdělávání je v současném kurikulu podchycena v RVP (Rámcový vzdělávací program) pro daný typ škol. Zde je zakotveno povinné vzdělávání ve vzdělávací oblasti informačních a komunikačních technologiích. Tato část je také ukryta např́klad v samotné vzdělávací části fyzika nebo chemie. Dále se můžeme s ICT setkat i v průřezových tématech, a to konkrétně v „mediální výchově“, která by sice mohla být zaměřena na ověřování platnosti informací získaných na internetu, ale proč do ní nezařadit např́íklad i práci s fyzikálními informacemi a jejich ověřování. (RVP ZV, 2013)

Rozvoj prírodních věd a ICT v posledních letech dává jasně najevo, že jejich odborná a školská část budou ICT stále více a více využívat. Musíme ale poznamenat, že RVP ZV (Rámcový vzdělávací program pro základní vzdělávání) ani RVPG (Rámcový vzdělávací program pro gymnázia) neříkají jak moc intenzivní práce a seznámení žáků s jednotlivými tématy má být.

\subsection{Užívání digitálních zař́izení a jejich vliv na změny v mozku}

Problém závislosti na mobilních zařízeních a internetu u dětí ale i dospělých, z níž se stává první stadium digitální demence, je řešen již od 90. let minulého století v technologicky nejvyspělejších zemích. Tento fakt s sebou přináší zhoršení kognitivních schopností objevujících u lidí, kteří utrpěli poranění hlavy nebo jsou duševně nemocní (The Daily Telegraph). Dalším je ztráta koncentrace na úkoly a změny v sociální sféře žáků nebo dospělých. V tomto ohledu citujeme výrok dr. Bjun Gi-won (Soul): „Př́liš časté použiváni chytrých telefonů a hernich zařizeni prekáži rovnovážnému vývoji mozku.“"

Všechno tak souvisí s tím, že zatěžujeme a následně rozvíjíme levou část mozku, která se vyvine více než pravá $\rightarrow$ snížení schopnosti soustředění a paměti zkoumané osoby. 


\subsection{Podpora digitálního vzdělávání ze strany českého státu}

OPVK Výzva č. 51, která byla zaměřena na další vzdělávání učitelů, (registrační čísla projektů $C Z .1 .07 / 1.3 .00 / 51 . x x x x$ ), díky které bylo možno do škol zakoupit učitelům maximálně 20 kusů mobilních (dotykových) zařízení (jak vyplývá z Př́lohy č. 5 Metodický výklad výzvy - Výzva č. 51 v oblasti podpory 1.3), zjistíme, že počet přijatých projektů je 46. Požadované finanční prostředky kumulativně jsou ve výši 1631522 175,96 Kč (Horáková, 2014). Základním záměrem Výzvy č. 51 je směřovat finanční podporu do základních škol, které mají méně než 200 žákủ, kterých je v ČR více než 50 \% (viz Př́loha č. 5 - Metodický výklad výzvy 51). Projekty končí k 31. 7. 2015.

\subsection{Podpora digitálního vzdělávání v zahraničí}

Na Slovensku byl mezi 12/2013-6/2014 realizován Pilotný projekt Škola na dotyk. V rámci projektu získalo patnáct škol technické vybavení (cca 400 tabletů Samsung Galaxy Note 10.1, 10 notebooků Samsung a 10 interaktivních tabulí), software pro správu tabletů, softwarovou a didaktickou podporu (řešení Samsung School) (Edukační laboratoř, 2015). Projektu se zúčastnilo 100 učitelů, s digitální technikou pravidelně pracovalo na 1000 žáků. Díky projektu bylo do škol dodáno dalších 20000 tabletů a jiné digitální techniky (Tasr, 2014).

Obdobný projekt, v podstatě totožný, je nyní realizovaný také v České republice, Škola dotykem 2014. Dvanáct škol během školního roku 2014/2015 používá tablety. Žáci i učitelé dostali k dispozici 350 tabletů (Samsung Galaxy Note 10.12014 Edition) (Edukační laboratoř, 2015).

Otázkou však zůstává, zda bylo dobře zvolit pouze jednu platformu, na které tablety pracovaly. Nenabízí jiná platforma jiné kvalitnější a kvalitněji zpracované aplikace? To je opět otázka, kterou si musí zodpovědět každá škola sama, podle potřeb pro své učitele a žáky.

\subsection{Mohou tablety nahradit tištěné učebnice?}

Pro tablety hovoří to, že absorbují nesčetné množství elektronických knih a učebnic. Výsledky výzkumů nejen v USA ukazují, že se úspěšnost žáků, kteří s nimi pracují, v testech zvyšuje Mock (2004), Galligan (2010), Hocanın (2014).

Proti hovoří jejich cena, která i při cca 5000 Kč může být pro školy nebo rodiče limitující. Dále se jedná o rušivý element ve výuce. Nehledě na zdravotní problémy (únava očí, bolesti hlavy nebo rukou a rozmazané vidění) Hocanın (2014). Také nesmíme zapomenout na technická omezení (sít' Wi-Fi, rychlé zastarávání tabletů). Jako další bod proti uvedeme zhoršenou pamět' jejich uživatelů, jak zjistila např́klad Kate Garland (2014) z univerzity v Leicesteru v Anglii nebo jak publikoval Isenberg (2014).

V grafu (Graf 1) je znázorněno, jak vnímají respondenti čtení papírových knih a e-knih. Je prŕjemné, že pro čtení s dětmi se stále rodiče (respondenti) uchylují k papírové knize $(81 \%)$. Také pro sdílení knih je preferovaná papírová verze knih (69 \%), zde ovšem může významnou roli hrát také mechanismus nákupu a práce s e-knihami. Zde je velmi nesnadné tyto zakoupené kopie dále šírit bez porušení autorských práv, i když se na této variantě pracuje. Pro čtení knih v posteli je situace velmi vyrovnaná (papírové $43 \%$ vs. e-knihy $45 \%$ ). Pro větší portfolio dostupných knih v daném okamžiku respondenti volí e-knihy (53\%) a pro čtení při cestování jsou pak 
e-knihy výrazně preferovány (73 \%). Pro rychlost získání nové knihy je preferována e-kniha (83\%). Pozn.: Součty respondentů v jednotlivých kategoriích nedávají $100 \%$. Zmiňovaný rozdíl je přisouzen respondentům, kteří nemají vyhraněný názor v dané sekci pro papírovou nebo e-knihu. Tablets vs. Textbooks (2014)

I přes zjevné výhody e-knih, se stále papírové knihy vyrábí. Z diskusí se studenty a některými respondenty usuzujeme, že klasická kniha u čtenáře vyvolává více emočního vzruchu než e-kniha (papír má vůni, barvu, patinu, můžeme v ní podtrhávat a dopisovat poznámky). Navíc mnoho respondentů uvedlo, že právě hmotnost klasické knihy je často donutí se z nich učit, aby je již nemuseli nosit s sebou.

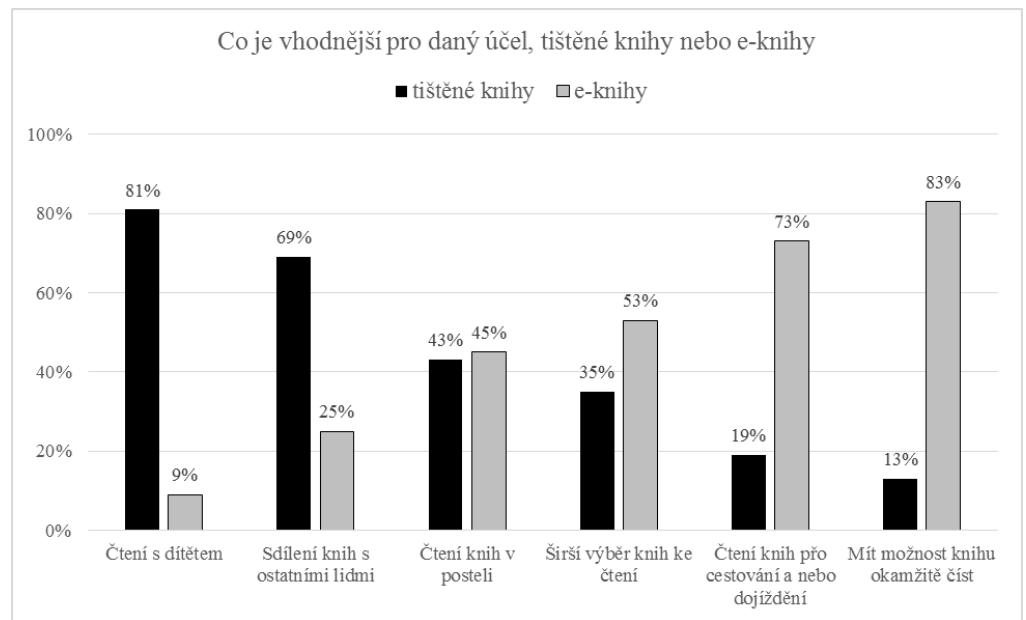

Graf 1: Porovnáni tištěné knihy a tabletu/e-knihy. Převzato a upraveno z: Tablets vs. Textbooks (2014)

\section{Použité výzkumné metody}

Cílem výzkumného šetření je zjistit současný stav využivání mobilních technologii ve školní výuce a posoudit i některé faktory ovlivňujici jejich adekvátní využití ve výuce. Za účelem dosažení výzkumného cíle byly stanoveny výzkumné otázky (označeny např. O1) a hypotézy (označeny nap̌r. H1), zde uvádíme pouze výběr.

O1: Použivají mobilni technologie častěji mladši učitelé než učitelé starší?

O2: Existuje vztah mezi délkou praxe učiteli a využiváním mobilních technologii ve školní výuce?

H1: Učitelé do 40 let věku včetně využivají mobilní technologie ve výuce či př́pravě na ni častěji než učitelé starší.

H2: Četnost využivání mobilnich technologií ve výuce či prípravě na ni závisí na délce pedagogické praxe. 
Jako výzkumnou metodu jsme zvolili dotazníkové šetření. Výzkumným nástrojem byl elektronický dotazník. Dotazník byl vytvořen podle metodiky tvorby dotazníků (Chráska, 2007), (Gavora, 2008). Při vyhodnocování dotazníků s uzavřenými, polouzavřenými, otevřenými a škálovanými odpověd’mi byly zjišt’ovány četnosti jednotlivých druhů odpovědí.

Vytvořený nestandardizovaný dotazník byl anonymní. V úvodu dotazníku je dopis respondentům, ve kterém jsou seznámeni s cílem výzkumu a ujištěni o anonymitě získaných odpovědí. V prvním oddílu dotazníku byly otázky zaměřené na zjištění demografických údajů o respondentech a otázky na popis školy, ve které vyučují. V další části dotazníku se otázky orientovaly na mobilní digitální technologie, které respondent vlastní nebo má $\mathrm{k}$ dispozici $\mathrm{v}$ rámci školy. Část otázek byla zaměřena na využívání mobilních digitálních technologií během př́ípravy a výuky. Další otázky byly zaměřené na prostojové učení. Také jsme se ptali respondentů, jaké důvody je vedou $\mathrm{k}$ tomu, že mobilní digitální technologie během vlastní výuky nepoužívají a proč.

Čas nezbytný k vyplnění finálního dotazníku byl 10 minut. Účast respondentů byla anonymní a dobrovolná. Za vyplnění testu nebyla poskytována žádná odměna.

Elektronický dotazník byl vytvořen ve webovém rozhraní veřejného elektronického formuláře GoogleDocs. Pomocí tohoto rozhraní byl také administrován a zpracováván. Vlastnímu spuštění předcházela fáze testování funkčnosti a správnosti. Testovací fáze se zúčastnilo 8 osob.

Byly testovány hypotézy o vzájemném vztahu mezi získanými údaji. Výsledky šetření budou představovat poznatky, které mohou využívat učitelé při prŕípravě do svých vyučovacích hodin, ale i metodici, kteří se budou tímto tématem dále hlouběji zabývat.

Pro statistické vyhodnocení hypotéz byly stanoveny nulové a alternativní hypotézy označované např. H10 (nulová hypotéza) a H1A (alternativní hypotéza). Pro určení statistické významnosti byly hypotézy ověřovány pomocí statistických metod používaných při testování hypotéz, konkrétně Test dobré shody chí-kvadrát (Hendl, 2004), (Chráska, 2007). V některých prŕpadech byly určeny stupně závislosti a těsnosti vztahu proměnných.

Pro popis dat získaných ve výzkumném šetrení byla použita deskriptivní statistika (Chráska, 2007). Jejím prostřednictvím byly zjišt’ovány četnosti jednotlivých odpovědí.

Při zpracování výzkumných šetření byla použita hladina významnosti $p \leq 0,05$. $\mathrm{V}$ pedagogické metodologii se tato hodnota standardně používá. Možnost nesprávného príijetí nebo zamítnutí nulové hypotézy byla tedy $5 \%$.

\section{Průběh a výsledky výzkumného šetření}

Výzkumného šetření se zúčastnili primárně studenti bakalářského oboru Učitelství praktického vyučování a navazujícího magisterského oboru Učitel odborných předmětů na Pedagogické fakultě MU v Brně. Šetření probíhalo od listopadu 2014 do ledna 2015. Celkově jsme požádali o odpověd’ 287 studentů uvedených oborů (základní soubor, $\mathrm{N}=287$ ), s tím že mohou dotazník dále šírit mezi dalši školy. Získali jsme 98 vyplněných dotazníkủ. Odpovědí, které jsme mohli použít do šetření, bylo 82 z toho 28 mužů a 54 žen (výběrový soubor, $\mathrm{n}=82$, velikost výběrového souboru odpovídá 28,6 \% základního souboru). Nejvíce respondentů bylo ze škol s počtem žáků v rozmezí 401-500, naopak s nejmenším počtem byly školy pod 100 žáků. 
Nyní prezentujeme pouze výběr z odpovědí a zpracovanou pouze jednu hypotézu H1. Pro ni jsme si stanovili hypotézu nulovou a alternativní:

H10: Neexistuje vztah mezi využiváním mobilnich a digitálních technologie ve výuce či prípravě na ni a věkem učitelü. Mladši učitelé ji nepouživaji častěji.

H1A: Existuje vztah mezi využiváním mobilnich a digitálnich technologie ve výuce či př́pravě na ni a věkem učitelů. Mladši učitelé ji použivaji častěji.

Kontingenční tabulka obsahuje získaná data vztahující se k dané hypotéze z dotazníkového šetření. Hodnoty bez závorek reprezentují pozorované četnosti odpovědí $P$ podle príslušných otázek. V závorkách jsou uvedeny hodnoty očekávané četnosti $O$, které odpovídají platnosti nulové hypotézy.

Tab. 1: Počty respondentů podle odpovědí na to, zda využivají mobilní digitální technologie ve výuce či prípravě na ni

\begin{tabular}{|c|c|c|c|}
\hline & $\begin{array}{l}\text { Učitelé do } 40 \\
\text { let věku vč. }\end{array}$ & $\begin{array}{l}\text { Učitelé nad } 40 \\
\text { let věku }\end{array}$ & $\Sigma$ \\
\hline $\begin{array}{l}\text { Využívá mobilní digitální technologie } \\
\text { ve výuce či př́ípravě na ni }\end{array}$ & $11(7)$ & $3(7)$ & 14 \\
\hline $\begin{array}{l}\text { Nevyužívá mobilní digitální } \\
\text { technologie ve výuce či př́ipravě na ni }\end{array}$ & $32(36)$ & $36(32)$ & 68 \\
\hline$\Sigma$ & 43 & 39 & 82 \\
\hline
\end{tabular}

Pro tabulku (Tab. 1) byla vypočítána hodnota testového kritéria $\chi^{2} H 1=4,623$. Kritická hodnota testového kritéria pro hladinu významnosti $p \leq 0,05$ a počet stupňu volnosti $f=1$ je $\chi^{2} 0,05(1)=3,841$. Protože vypočítaná hodnota testového kritéria $\chi^{2} H I$ je vyšší než hodnota kritická $\chi^{2} 0,05(1)$, přijímáme hypotézu alternativní. Pro zkoumaný vzorek bylo zjištěno, že existuje vztah mezi využíváním mobilních a digitálních technologie ve výuce či př́pravě na ni a věkem učitelů.

Pro dokreslení síly vztahu byla zjištěna ještě hodnotu normovaného koeficientu kontingence $C_{\text {norm }}$. Po dosazení získáváme hodnotu $C_{n o r m H l}=0,26$. $\mathrm{Z}$ tohoto pohledu je síla závislosti nízká.

Mezi zkoumanými jevy tedy existuje statisticky významná závislost. Protože se v tomto př́ípadě jedná o čtyřpolní tabulku, můžeme $\mathrm{k}$ posouzení stupně závislosti jednotlivých znaků v tabulce použit Yulův koeficient asociace $Q$. Pro tento př́ípad je $Q_{H I}=0,61$, což reprezentuje silnou jednostrannou závislost v dané tabulce (Chráska, 2007).

V rámci dotazníku jsme se také respondentů dotazovali, zda znají výukovou metodu prostojové učení. Ne odpovědělo $95 \%$ respondentů, ano $5 \%$ respondentů. Na otázku, která s tímto tématem souvisí, a to Zda již někdy použili m-learning ve svojí výuce odpovědělo $92 \%$ respondentů ne a $8 \%$ respondentů ano. Oba výsledky ukazují, že metoda prostojové učení není respondentům zatím známa. 
Při pohledu na platformy tabletů uvedli respondenti, kteří používají tablety ve výuce (44 \% respondentů), že $76 \%$ jich používá ve škole Android a $23 \%$ iOS, do zbylého $1 \%$ jsme sloučili ostatní platformy.

\section{Diskuze a výsledky}

Výsledky výzkumného šetření ukázaly, že současní učitelé (respondenti) mají strach experimentovat $\mathrm{s}$ aplikacemi, které by mohli použivat pro svoji výuku. Také jim chybí seznam aplikací do jednotlivých předmětů, které mohou použivat pro ty které úkoly a žákovskou práci. Současně s tímto faktem se ukázalo, že mnoho z nich se neorientuje v Obchodech (Storech), kde se získávají aplikace pro daný typ mobilního zařízení. Domníváme se, že by to mohlo souviset $\mathrm{s}$ některými oprávněními, které uživatel při instalaci aplikace musí povolit. To souvisí hlavně s operačním systémem Android (tato skutečnost by již nemusela hrát tak významnou roli s př́chodem nové verze Android 6.0 Marshmallow, kde lze u některých aplikací částečně tato práva měnit). Seznamy aplikací, které lze používat $\mathrm{v}$ jednotlivých předmětech postupně vznikají, nicméně jsou známější spíše uvnitř dané komunity. Například pro učitele fyziky tyto seznamy již vytvořil a aktualizuje R. Kusák z Dvořákova gymnázia v Kralupech nad Vltavou. Dalším problémem je jazyková bariéra.

Mimo jiné jsme u respondenti̊ $\mathrm{s}$ větší délkou pedagogické praxe, pozorovali pokles četnosti vyžití mobilní techniky ve výuce či př́pravě na ni. Tento jev si vysvětlujeme tím, že začínající učitelé studovali již v době zavádění digitálních technologií do populace. Pro některé respondenty v blízkosti důchodového věku nemusí být využití mobilních technologií ve výuce zajímavé, príípadně již odmítají s ní vůbec pracovat.

Při bližším pohledu na výsledky jiných výzkumů provedených jak pouze v ČR tak i celoevropského rozsahu můžeme uvést např́klad TALIS (Teaching and Learning International Survey - zaměřující se na úroveň znalostí a dovedností učitelů a vedení škol) (Kašparová, 2013), PIAAC (Programme for International Assessment of Adult Competencies), který realizovalo OECD. Jeho cílem bylo zjistit, jak jsou obyvatelé zúčastněných zemí připraveni na život v moderní společnosti (Kelblová, 2013) nebo "Survey of schools ICT in education: benchmarking access, use and attitudes to technology in Europe's schools“ (2013) zjistíme, že dovednosti pracovat s ICT českých učitelů a žáků vzhledem $\mathrm{k}$ evropskému průměru není nikterak špatné, ovšem v mnoha ohledech jsme daleko za špičkou. To platí pro infrastrukturu, která je při práci s mobilními technologiemi potřeba posílit nebo teprve vybudovat. Také dotazovaní učitelé a žáci považují ICT za doplněk v jejich výuce, nikoli za základní stavební kámen. To souvisí s tím, že existuje rozpor mezi využiváním technologií ve školách a mimo ně.

\section{Mobilní aplikace vhodná pro zařazení do výuky}

Mohlo by se zdát, že cílené použíání ICT a jiných mobilních technologií do přírodovědných předmětů není pro žáka žádným přínosem. Opak je pravdou. Žák vědomě aplikuje získané vědomosti, dovednosti či návyky př́mo do své pracovní činnosti. Ihned tak vidí, že se neučí pro známky, ale pro život. Naším dlouhodobým cílem je tedy aplikovat do školské výuky takový podpůrný nástroj, který žákovi umožní výše uvedené. 
Pro jednotlivé mobilní platformy (Android, iOS, Windows Phone, Tizen, Bada) je produkováno mnoho aplikací použitelných ve školské výuce. Dále uvedené aplikace jsou odzkoušené a určené pro tablety nebo mobilní telefony s operačními systémy Android. Operační systém Windows Phone a ostatní mobilní operační systémy mají základnu uživatelů neporovnatelně menší a výukové aplikace prakticky neexistují.

V aplikaci AndroSensor (Android) (free verze) můžeme používat vestavěné snímače $\mathrm{v}$ telefonu nebo tabletu pro různá měření fyzikálních veličin, které vystupují v různých experimentech. Namátkou se může jednat o zrychlení, hlasitost zvuku, intenzitu magnetického pole, intenzitu světla, úhel náklonu nakloněné roviny, teplota, tlak a další veličiny. Získaná data $\mathrm{z}$ měření pak jsou prezentována textově i graficky. Př́ípadně je umožněn export dat do CSV souboru, se kterým lze pracovat v běžných tabulkových procesorech.

\section{Závěr}

Mobilní zařízení nabízí mnoho aplikací, které může použít jak žák, tak učitel ve výuce. Primárně by to však měly být takové aplikace, které uživatelům budou usnadňovat práci, např́klad školní agendu nebo zpracování experimentů. Je tedy nutné, aby s těmito zařízeními byl schopen pracovat jak učitel, tak žák na shodné úrovni. Tyto nároky, které jsou kladeny na práci učitelů, jdou ruku $\mathrm{v}$ ruce se současnými požadavky na používání digitálních technologií v běžném životě.

Přináší $\mathrm{s}$ sebou ovšem značná nebezpečí a to $\mathrm{v}$ podobě zdravotních problémů, pamětních a sociálních. Mimo jiné také mnoho aplikací požaduje zcela nelogické povolení př́stupu $\mathrm{k}$ často citlivým datům majitel (GPS souřadnice, kontakty, SMS, ...). Je tak nutné vždy zvážit, zda daná pomůcka přináší do výuky ten správný užitek.

Pokud se zaměříme na otázku vynakládání financí na vybavení škol tablety, je nutné se zaměřit na správnou skupinu, která s nimi bude pracovat. Pokud se jedná o „zdravou“ populaci, je prínos tabletů nebo jiných mobilních digitálních zařízení někdy diskutabilní, viz výše. Situace se nám ovšem mění při nasazení tabletů do výuky tělesně nebo mentálně znevýhodněných osob. Zde nám tato zařízení pomáhají lépe edukovat uvedené osoby a zvýšit tak jejich začlenění do majoritní společnosti.

Na konkrétních aplikacích, které si může každý učitel, ale i žák, nainstalovat do svého mobilního zařízení lze ukázat mnoho závislostí a jevů. Ruku v ruce s př̌edchozím je také posílena žákova schopnost zjištovat základy a principy fungování prírodních procesů a jevů, které zná z každodenního života a to navíc nezávisle na jeho analytickém a logickém myšlení.

Celkově tedy můžeme říci, pokud by mohly nebo jsou mobilní technologie vhodným prostředkem pro výuku $\mathrm{v}$ prrírodovědných předmětech současných žáků, pak se $\mathrm{s}$ nimi nesetkávají v takové míře, jaká by jim mohla být nápomocna. Učitelů, kteří uvedené technologie používají, není v našem vzorku mnoho, 14 z 82 respondentů. Zároveň metody m-learningu nebo prostojového učení nejsou respondentům nijak výrazně známé, což se také projevuje do výsledků šetření.

Dalším logickým důsledkem je rozšíření výzkumného šetření zaměřeného na žáky, zda jim používání mobilních technologií připadá jako adekvátní pro využití ve škole. 


\section{Literatura}

EDUkační LABoratoř. (2015). $O$ projektu. [online]. Dostupné z WWW: <http://www.skoladotykem.cz/o-projektu.html>.

Galligan, L., Loch, B., McDonald, C., \& Taylor, J. (2010). The use of tablet and related technologies in mathematics teaching. Australian Senior Mathematics Journal, [online].

Dostupné z WWW: 〈http://files.eric.ed.gov/fulltext/EJ891808.pdf〉.

Garland, K. (2014). Paper v Digital. In: Knowing and organising to anticipate changes.

Brussels. [online]. Dostupné z WWW:

https://www.ucs.ac.uk/About/Structure/UCSStaffProfiles/Department-of-Children-

Young-People-and-Education/images/Paper-v-Digital-Overview.pdf

Gavora, P. (2008). Úvod do pedagogického výskumu. Bratislava: Univerzita Komenského Bratislava.

Generation Y. (1993). Advertising Age, Vol. 64 (Issue 36), pp. 16.

Groom, D. (2011). The Downtime Learner theory. [online]. Dostupné $\mathrm{z} W W W$ : <http://deangroom.wordpress.com/2011/04/14/the-downtime-learner-theory>.

Hartl, P., \& Hartlová, H. (2000). Psychologický slovnik. Praha: Portál.

Hocanın, F., Iscioglu, E. (2014). Use Of Mobile Tablets In The Learning Environment: Perspective Of The Computer Teacher Candidates. In: Kafes, H., Istifci, I., \& Caner, M. International Journal on New Trends in Education and Their Implications: JOURNAL OF EDUCATIONAL AND INSTRUCTIONAL STUDIES IN THE WORLD. Turecko.

Horáková, P. (2014). Vyhlášeni výzvy k předkládáni individuálnich projektů ostatních Oblast podpory 1.3 - Dalši vzděláváni pracovníků škol a školských zařizení. [online].

Dostupné z WWW:

<http://www.opvk.cz/redakce/index.php?clanek=227396\&lanG=cs\&xuser $=43231158188$ $6157433 \&$ slozka $=10 \&$ xsekce $=223018 \&$ xsekce $=223018>$.

Isenberg, B. (2014). Paper is still king. In: Print Matters. USA: Johnson Press of America. [online]. Dostupné z WWW:

<http://www.jpapontiac.com/newsletters/March2014.pdf>.

Kašparová, V., Boudová, S., Ševců, M., \& Soukup, P. (2014). Národní zpráva šetření TALIS 2013. Praha: Česká školní inspekce.

Kelblová, L., \& Modráček, Z. (2013). Dovednosti české populace v prostředi informačnich technologií. Praha: Dům zahraniční spolupráce.

Lohr, M. (2013). IPad Or PC: Comparing Tablets And PCs For Science Teaching Purposes. In: Open Discovery Space. [online]. Dostupné zWWW: <http://opendiscoveryspace.eu/sites/ods/files/lohr_final_paper_end2013_nr334.pdf>.

Mock, K. (2004). Teaching With Tablet PC'S. In: Journal of Computing Sciences in Colleges. USA. [online]. Dostupné z WWW: <http://www.math.uaa.alaska.edu/ $\sim$ afkjm/papers/mock-ccsc2004.pdf>.

MŠMT. (2013). Hlavni směry Strategie vzdělávací politiky 2020: Vstupni materiál do veřejné konzultace $k$ př́pravě Strategie vzdělávaci politiky České republiky do roku 2020. Praha.

Oblinger, D., \& Oblinger, J. (2005). Is It Age or IT: First Steps Toward Understanding the Net Generation. In Oblinger, D., \& Oblinger, J. Educating the net generation.. Boulder, CO: EDUCAUSE.

Průcha, J., Walterová, E., \& Mareš, J. (1995). Pedagogický slovník. Praha: Portál. 
Robinson, M. (2013). The Generations: What Generation are You?. [online]. Dostupné z WWW: 〈http://www.careerplanner.com/Career-Articles/Generations.cfm>.

Schroer, W. (2004). Generations $X, Y, Z$ and the Others - Cont'd. [online]. Dostupné z WWW: 〈http://www.socialmarketing.org/newsletter/features/generation3.htm>.

Siemens, G. (2004). Connectivism: A Learning Theory for the Digital Age. [online]. Dostupné z WWW: 〈http://www.elearnspace.org/Articles/connectivism.htm>.

Survey of schools ICT in education: benchmarking access, use and attitudes to technology in Europe's schools. (2013). Luxembourg: Publications Office.

Tablets vs. Textbooks - ProCon.org: Should Tablets Replace Textbooks in K-12 Schools? [online]. (2014-09-04). Dostupné z WWW: 〈http://tablets-textbooks.procon.org〉.

TASR. (2014). Tablety sa $v$ školách osvedčili, chcú ich učitelia $i$ žiaci. [online]. Dostupné z WWW: <www.minedu.sk/tablety-sa-v-skolach-osvedcili-chcu-ich-ucitelia-iziaci>.

Tulgan, B. (2013). Meet Generation Z: The second generation within the giant "Millennial" cohort. RainmakerThinking. [online]. Dostupné z WWW: <http://rainmakerthinking.com/assets/uploads/2013/10/Gen-Z-Whitepaper.pdf〉. Výročni zpráva o stavu a rozvoji vzdělávánív České republice v roce 2013: Vzdělávání v roce 2013 v datech. (2014). Praha: Ministerstvo školství, mládeže a tělovýchovy. 